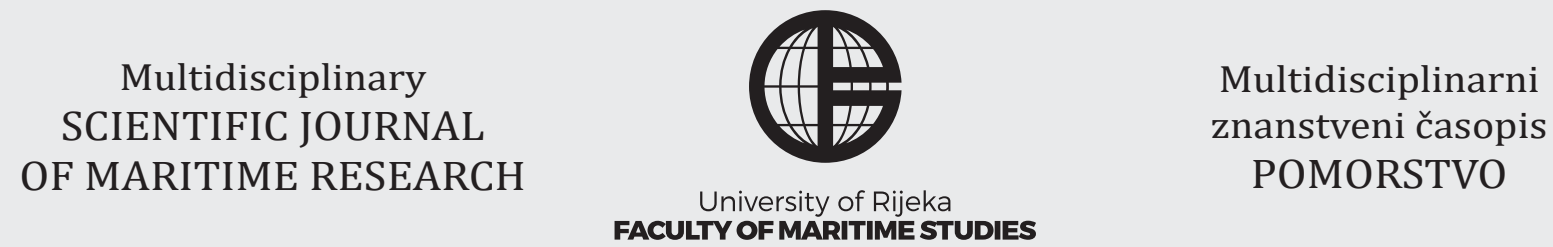

https://doi.org/10.31217/p.33.2.14

\title{
Harmonization of Kosovo's Legislation with the Acquis Communautaire in the Field of Transport - The Case of Sea Ports Exploitation
}

\author{
Fitore Morina \\ University of Prishtina "Hasan Prishtina”, Faculty of Law, Rr. George Bush, pn, 10000 Prishtina, Republic of Kosovo, e-mail: fitore.morina1@uni-pr.edu
}

\section{ABSTRACT}

The aim of this paper is to present the position of Kosovo from the perspective of exchange, trade and movement of goods and capital, exploiting the benefits of multimodal transport and in particular the exploitation of maritime transport. Initially, this paper addressed the development of multimodal transport in Kosovo by analyzing the legal cooperation of Kosovo with the state and region. The focus of the work is the treatment of multimodal and maritime transport, and the impact on the increase of the level of cooperation besides the economic one in the cultural, educational and tourist aspect. In this paper, comparative, historical, normative and statistical methods have been used to explain the role and importance of the exploitation of the seaports of the countries of the region. Finally, the measures taken to harmonize Kosovo's legislation with the acquis communautaire in the field of transport have been addressed in this paper.

\section{ARTICLE INFO}

\section{Review article}

Received 5 May 2019

Accepted 26 June 2019

\section{Key words:}

Maritime transport

Harmonization of Legislation

Kosovo

\section{Introduction}

The growth of the level of international cooperation in the field of trade in goods and services in the framework of EU Member States is considered as its main objective. Therefore, the international trade of goods is developed using various forms of transport, such as road, rail, air and sea transport. However, some countries do not allow the direct use of the facilities that maritime transport can make due to their geographical position and geographical extent. One of the countries in the South Eastern part of Kosovo is Kosovo, a country that lies in the center of the Balkan Peninsula, and is bordered to the southwestern part of Albania, which in the west is wetted with the seas: the Adriatic and Ionian, which is only $78 \mathrm{~km}$ away Italy along the Otranto's canal. Therefore, the lack of ports in Kosovo has been covered by negotiating and reaching bilateral agreements with Albania, which by the length of the borderline of the Republic of Albania is $1094 \mathrm{~km}$, while the coastline has $316 \mathrm{~km}$. To provide and facilitate the transportation of goods from seabed, Kosovo has undertaken a series of initiatives to create facilities for access to maritime and port services through Albania. Therefore, the imitative need for strategic planning and planning of transport policy in Kosovo has been harmonized with the EU acquis communautaire for transport and fiscal policies and Kosovo's financial and development programs. The development of multimodal transport, while enabling the growth and the economic development of the country, also facilitates the increase of the level of cultural, educational and tourist cooperation. It also offers more stable and long-term cooperation in the countries. The lack of intermodal rail transport between Kosovo and Albania significantly affects the economic-financial cost of users of multi-modal transport but also directly affects passengers in general.

Currently, in Kosovo there is a railway line with the capital of Serbia and Macedonia but there is no railway infrastructure with Albania and Montenegro. Therefore, the EU considers that for the functioning of the common European market for its member states and for countries aspiring to EU membership (such as Albania and Kosovo), is the multimodal transport development using the advantages of each type of transport and integrating them in a common European system. Kosovo authorities have carried out specific analyzes of the potential exploitation 
of a seaport of countries in the region for the purpose of customs clearance of goods destined for Kosovo. Kosovo has prepared special agreements with the authorities of the respective ports in Albania, compiled in accordance with the current international regulations with a view to facilitating the transit of port transit related to free trade areas in seaports and for the application of customs facilities with the case of customs clearance. Kosovo has signed an agreement for the exploitation of the seaport of Durres and the seaport of Shengjin.

\section{Kosovo's access to the Sea Ports of the region}

The emergence of Kosovo's exit will significantly affect Kosovo's economic development will also affect tradeeconomic relations between Kosovo and Albania, and both economies in relation to the countries of the region and the countries of Europe. The issuance of the port of Shengjin with concession to the state of Kosovo in 2009 marks the first agreement of this kind for Albania, but also for the state of Kosovo. Also, Kosovo has signed other bilateral agreements with the authorities of the seaports of the countries of the region, such as the signing of the agreement with Greece for the seaport of Thessaloniki, as well as the signing of the agreement with Montenegro for the seaport sea port. So, to realize the sea transport, Kosovo harbors the ports of neighboring countries, including the port of Durres, the largest port in Albania, where $78 \%$ of the national maritime trade is currently developing, and taking advantage of its position with and the biggest in the Adriatic and Ionian seas, this port facilitates Kosovo's trade with other countries, due to the fact that the road distance is short (about $260 \mathrm{~km}$ ). The above-mentioned ports have different floating depths, such as the max. Depth of the floating depth, for example. Shengin port has a maximum depth of $6.5 \mathrm{~m}$ compared to the port of Durres which is $10 \mathrm{~m}$, the port of Tiiv has the maximum depth of $14.0 \mathrm{~m}$, and Thessaloniki $15.0 \mathrm{~m}$. If we compare the length of the bed we can see that the port of Shengjin is $80 \mathrm{~m}$, while the port of Durres $2200 \mathrm{~m}$, that of the bar of $3500 \mathrm{~m}$ and Thessaloniki $3900 \mathrm{~m}$. Tivari (Black Mountain) has a port space of 2,000 ha and 20 village settlements / beds.

Includes a container terminal area. Whereas, the port of Durres (Albania) has a port space of 138 hectares and 11 helicopters / beds. In addition to the maximum ship size (DWT) in Shengjin is 5000, in Durres 25,000, in Bar 40000, and in Thessaloniki is 60000 . If we take the base of the distance from Pristina to the port of Shengjin is about $207 \mathrm{~km}$, the port of Durres is about $260 \mathrm{~km}$ away with the port of Tivar $430 \mathrm{~km}$ while with the port of Thessaloniki the road is about $320 \mathrm{~km}$. Therefore, the exploitation of maritime transport on goods trading in Kosovo, taking into account the characteristics of each port of neighboring countries, can be understood as the possibility that the economic cost is lower if the ports of Shengjin and Durres are used because of the distances the shortest road. Making use of the seaports of neighboring countries goes through some pro- cedures that have legal-administrative, economic and political implications. The road link between Kosovo and Albania has advanced with the completion of the two-lane highway in both directions and with cross-border facilities. For the development of access to other ports, special importance is their connection to the landline. To this end technical and economic studies are needed to find a sustainable solution [1]. Initially, political agreement is needed with regard to the exploitation of seaports and then the submission of public-private partnerships (PPPs). The contracting authorities of the states concerned prepare the feasibility study before undertaking a commitment for the implementation of the project.

The feasibility study consists of three phases [2]:

- The first phase provides for the review and evaluation of the technical, economic and commercial aspects of a proposed project, which will serve as a basis for the investment decision.

- The second phase contains the main features of the project, based on technical, economic and financial analysis as well as the environmental and social impact analysis carried out in view of the planned investment.

- The third phase should focus on analyzing whether the project designed as a PPP concession is economically advantageous.

After the signing of the agreement between Kosovo and Albania, the feasibility study for using the Shëngjin port from Kosovo has been completed by the end of 2018 [1]. The rapid access to the ports of Durres and Shengjin enabled businesses in Kosovo to have only one supply corridor through Thessaloniki or Tivari but helped reduce costs by about 50\% compared to Greece and Montenegro and also contributed in GDP growth in Albania due to increased trade exchanges and customs tariffs. According to statistics of the Institute of Statistics of Albania, the construction of road transport through the Nation's Highway adds to the level of trade exchange between Kosovo and Albania.

\section{Multimodal Transport Policies in the EU}

The definition of the common legal framework within the European Community regarding multimodal transport is very dimensional, including the environmental, trade and political factors. Therefore, EU legislation otherwise known as the acquis communautaire in recent years port legislation has been subject to reforms related to the establishment of sustainable ports in the Adriatic-Ionian region whose purpose is to support port authorities in developing and implementation of local action plans for low carbon transport [3]. The multimodal transport system in the EU is being challenged with the problem of high fuel consumption, causing large CO2 emissions and environmental degradation. In 2008, the EU has prepared a Marine Strategy Framework Directive [6] that deals with the most effective marine environment protection in Europe. In 2017, this strategy has been revised and has es- 
tablished the legal framework for accessing ecosystems in the management of human activities that have an impact on the marine environment, integrating the concepts of environmental protection and sustainable use. Pursuant to Article 6 of the Directive, Member States are required to use the institutional structures and activities of the RSC to facilitate the implementation of the Directive, notably in relation to third countries. There are four European Regional Sea Conventions:

- The Convention for the Protection of the Marine Environment in the North-East Atlantic of 1992 (further to earlier versions of 1972 and 1974) - the OSPAR Convention (OSPAR)

- The Convention on the Protection of the Marine Environment in the Baltic Sea Area of 1992 (further to the earlier version of 1974) - the Helsinki Convention (HELCOM)

- The Convention for the Protection of Marine Environment and the Coastal Region of the Mediterranean of 1995 (further to the earlier version of 1976) - the Barcelona Convention (UNEP-MAP) Shetet anetare: Albania, Algeria, Bosnia and Herzegovina, Croatia, Cyprus, Egypt, the European Community, France, Greece, Israel, Italy, Lebanon, Libya, Malta, Monaco, Montenegro, Morocco, Slovenia, Spain, Syria, Tunisia, Turkey.

- The Convention for the Protection of the Black Sea of 1992 - the Bucharest Convention.

The European Commission has prepared a strategy for multimodal transport 2050 which foresees a competitive transport system that will be in the function of increasing the movement and employment in the EU area [4]. The following measures are foreseen in this strategy:

Reforming the legal framework of EU multimodal transport with new financing opportunities and conditions.

- Calculation of all costs for the use of multimodal transport in order to cover the costs of $\mathrm{CO} 2$ emissions, pollution of the environment, noise and accidents.

- Applying the principle of destination to revenue collected by transport users.

- Production of all non-polluting, safe and unsafe means of transport, including: vehicles, ships, planes, boats and other means of transport.

- Integrated ticketing application in multimodal transport.

- Exploitation of alternative fuels and new materials.

- Increasing transport efficiency and infrastructure by using market-based information and market-based incentives.

- Financing multimodal transport in the period 20192030 by the EU is estimated at 1.5 trillion Euros.

- By 2050, the use of aviation fuel should be reduced by $40 \%$ and will automatically reduce pollution from ships.

Maritime transport in the EU has always been considered a catalyst for economic development and prosperity throughout history, so special attention has been paid to it.
The aspiration of Kosovo as a new state is to integrate into the European community even in the field of multimodal transport. Therefore, the undertaking of measures for approximation-harmonization of legislation in the field of transport, have started alongside the approach in other areas. At the end of 2018, according to the Constitution of Kosovo, Article 18 stipulates that the ratification of international agreements is made by the Assembly of Kosovo by $2 / 3$ of the votes. The agreement between the EU and Kosovo has been ratified and the law entered into force (No. 06 / L-109) on the ratification of the Treaty Establishing the Community of Transport, which aims at ratifying the Treaty establishing the Community of Cargo [8] between the EU and the countries of Southeast Europe, including: Kosovo, Albania, Bosnia and Herzegovina, the Former Yugoslav Republic of Macedonia, Montenegro and Serbia.

\section{Conclusion}

Increasing the level of trade exchange between different countries is almost almost impossible unless all types of transport are used. Therefore, the change of the dynamics of the markets of the region has changed significantly since the beginning of the deepening of trade-economic cooperation among the Balkan states. Offering Kosovo's exploitation of Albania's seaports has had a high impact on the export growth of Kosovo's products. The tendency to eliminate fiscal, administrative and political barriers between states contributes significantly to increasing the level of trade co-operation.

\section{References}

[1] Strategjia Sektoriale dhe Transportit Multimodal 2015- 2025 dhe Plan i veprimit 5 vjeçar, Tetor 2015. Republika KosovaRepublic of Kosovo, Ministry of Infrastructure.pp. 15-63.

[2] VENDIM Nr. 575, date 10.7.2013 Për miratimin e rregullave për vlerësimin dhe dhënien me koncesion/partneritet publik privat PPP, Autoriteti Portual Durres.

[3] SUPAIR - Porte të qëndrueshëm në Rajonin Adriatiko - Jonian publikon udhëzimet për portet eko-të qëndrueshme, 2018.

[4] WHITE PAPER Roadmap to a Single European Transport Area - Towards a competitive and resource efficient transport system, 2011.

[5] Retrieved from the world wid web on 27th of March from: http://ec.europa.eu/environment/marine/eu-coast-andmarine-policy/marine-strategy-framework-directive/index_en.htm

[6] Directive 2008/56/EC of The European Parliament and of the Council of 17 June 2008 establishing a framework for community action in the field of marine environmental policy (Marine Strategy Framework Directive).

[7] Retrieved from the world wid web on 24th of March from: http://ec.europa.eu/environment/marine/internationalcooperation/regional-sea-conventions/barcelona-convention/index_en.htm

[8] Gazeta zyrtare e Republikës së Kosovës / nr. 20 / 26 nëntor 2018, Prishtinë Ligji nr. 06/l -109 për ratifikimin e traktatit që themelon komunitetin e transportit. 